Electronic Supporting Information

\title{
Kinetics of Ferritin Self-assembly by Laser Light Scattering: Impact of Subunit Concentration, pH and Ionic Strength
}

\author{
Abhinav Mohanty ${ }^{1}$, Mithra K. ${ }^{2}$, Sidhartha S. Jena ${ }^{* 2}$, Rabindra K. Behera*1 \\ ${ }^{1}$ Department of Chemistry, National Institute of Technology, Rourkela - 769008, Odisha, India. \\ ${ }^{2}$ Department of Physics and Astronomy, National Institute of Technology, Rourkela - 769008, \\ Odisha, India.
}

*Co-Corresponding Authors. To whom correspondence should be addressed:

Rabindra K. Behera, Tel: +91-661-2462980; E-mail: beherarabi@ nitrkl.ac.in

Sidhartha S. Jena, Tel: +91-661-2462727; E-mail: sid@,nitrkl.ac.in

Keywords: Ferritin, Self-Assembly, Laser Light Scattering, Hydrodynamic Size, Rayleigh Equation. 
Table S1: The hydrodynamic radii and the half-lives along with the amplitudes (for both rapid and slow phase) of the self-assembly reaction of ferritin under different reaction conditions. The hydrodynamic radii $\left(\mathrm{R}_{\mathrm{h}}\right)$ were determined from DLS (Eq.1-2), the apparent half-lives $\left(\left(\mathrm{t}_{1 / 2}\right)_{1}\right.$ for rapid phase and $\left(t_{1 / 2}\right)_{2}$ for slow phase) and the amplitude ( $A_{1}$ for rapid phase and $A_{2}$ for slow phase) were determined from the non-linear fitting of kinetic profiles using double hyperbolic equation (Eq.3), as described in detail in the Experimental Section.

\begin{tabular}{|c|c|c|c|c|c|c|c|}
\hline \multirow{2}{*}{ Parameter } & \multirow{2}{*}{ Variation } & \multicolumn{2}{|c|}{$\begin{array}{c}\text { Hydrodynamic Radius }\left(\mathbf{R}_{\mathbf{h}}\right) \\
\text { (in } \mathbf{n m})\end{array}$} & \multicolumn{2}{|c|}{$\begin{array}{c}\text { Apparent Half-Life } \\
\text { (s) }\end{array}$} & \multicolumn{2}{|c|}{ Amplitude } \\
\hline & & $\begin{array}{c}\text { Dis-assembled } \\
\text { state }\end{array}$ & $\begin{array}{c}\text { Re-assembled } \\
\text { state }\end{array}$ & $\left(\mathbf{t}_{1 / 2}\right)_{1}$ & $\left(t_{1 / 2}\right)_{2}$ & $\mathbf{A}_{1}$ & $\mathbf{A}_{2}$ \\
\hline \multirow{4}{*}{$\begin{array}{l}\text { Protein } \\
\text { Concentration } \\
\text { (C) }(\text { in } \mathrm{mg} / \mathrm{mL})\end{array}$} & 0.05 & $1.5 \pm 0.2$ & $6.5 \pm 0.3$ & $56 \pm 3$ & $2724 \pm 198$ & 0.76 & 0.12 \\
\hline & 0.10 & $1.5 \pm 0.5$ & $6.8 \pm 0.3$ & $50 \pm 3$ & $1968 \pm 83$ & 0.80 & 0.18 \\
\hline & 0.15 & $1.6 \pm 0.2$ & $6.7 \pm 0.1$ & $20 \pm 3$ & $1871 \pm 113$ & 0.80 & 0.20 \\
\hline & 0.25 & $1.4 \pm 0.4$ & $6.6 \pm 0.2$ & N.D.* & $460 \pm 127$ & 0.82 & 0.18 \\
\hline \multirow{4}{*}{$\begin{array}{l}\text { Final } \mathrm{pH} \text { of the } \\
\text { medium }\end{array}$} & 5.50 & $1.4 \pm 0.4$ & $6.7 \pm 0.2$ & $27 \pm 2$ & $907 \pm 65$ & 0.84 & 0.16 \\
\hline & 6.50 & $1.5 \pm 0.2$ & $6.7 \pm 0.1$ & $47 \pm 2$ & $1756 \pm 70$ & 0.82 & 0.18 \\
\hline & 7.00 & $1.5 \pm 0.5$ & $6.8 \pm 0.3$ & $50 \pm 3$ & $1968 \pm 83$ & 0.80 & 0.18 \\
\hline & 7.50 & $1.4 \pm 0.3$ & $6.4 \pm 0.1$ & $104 \pm 5$ & $1279 \pm 38$ & 0.65 & 0.35 \\
\hline \multirow{4}{*}{$\begin{array}{l}\text { Ionic Strength } \\
(\mu) \text { of the } \\
\text { medium } \\
\text { (in } M)\end{array}$} & 0.45 & $1.5 \pm 0.5$ & $6.8 \pm 0.3$ & $50 \pm 3$ & $1968 \pm 83$ & 0.80 & 0.18 \\
\hline & 0.55 & $1.6 \pm 0.1$ & $6.7 \pm 0.2$ & $25 \pm 2$ & $1105 \pm 61$ & 0.78 & 0.21 \\
\hline & 0.60 & $1.4 \pm 0.2$ & $6.5 \pm 0.2$ & $17 \pm 2$ & $194.1 \pm 10$ & 0.79 & 0.17 \\
\hline & 0.70 & $1.5 \pm 0.2$ & $6.8 \pm 0.1$ & N.D.* & $96 \pm 27$ & 0.80 & 0.20 \\
\hline $\begin{array}{c}\text { Dis-assembling } \\
\text { Agents }\end{array}$ & $\begin{array}{c}\mathrm{GdnHCl} \\
(8 \mathrm{M} \text { to } 0.8 \mathrm{M})\end{array}$ & $1.4 \pm 0.2$ & $6.8 \pm 0.1$ & N.D.* & $1747 \pm 55$ & 0.56 & 0.44 \\
\hline
\end{tabular}

*N.D: Not Determined. Reaction exhibited too fast kinetics to obtain the kinetic parameters. 
Table S2: Refractive index increment $(\mathrm{dn} / \mathrm{dC})$ values for assembled, dis-assembled and re-assembled states of ferritin. These values were determined from the slope obtained from the linear fitting of $n$ vs. C (from Fig.S4), where $n=$ refractive index of the sample and $\mathrm{C}=$ protein concertation.

\begin{tabular}{|c|c|}
\hline State of the protein @ pH & $\mathbf{d n} / \mathbf{d C}(\mathbf{m L} / \mathbf{g})$ \\
\hline Assembled state @ pH 7.0 & $0.193 \pm 0.019$ \\
\hline Dis-assembled state @ pH 1.5 & $0.263 \pm 0.022$ \\
\hline Re-assembled state @ pH 7.0 & $0.239 \pm 0.025$ \\
\hline
\end{tabular}

Table S3: Molecular weight $\left(\mathrm{MW}_{\mathrm{w}}\right)$ and second virial coefficient $\left(\mathrm{A}_{2}\right)$ obtained from the Debye Plot (shown in Fig.3) using Eq.4-7 as described in the Experimental Section.

\begin{tabular}{|c|c|c|c|c|c|}
\hline State of the protein @ pH & $\begin{array}{c}\text { Intercept } \\
\text { (1/Da) }\end{array}$ & $\begin{array}{c}\text { Estimated } \\
\text { Molecular } \\
\text { Weight } \\
\text { (Mw, kDa) }\end{array}$ & $\begin{array}{c}\text { Known } \\
\text { Molecular } \\
\text { Weight } \\
\text { (Mw, kDa) }\end{array}$ & $\begin{array}{c}\text { Slope } \\
\left(\mathrm{mL} \cdot \mathrm{mol} / \mathrm{g}^{2}\right)\end{array}$ & $\begin{array}{c}2^{\text {nd }} \text { Virial } \\
\text { Coefficient } \\
\left(A_{2}, \text { mL.mol/g } \mathbf{g}^{2}\right) \\
\left(\times \mathbf{1 0}^{-3}\right)\end{array}$ \\
\hline Assembled state @ pH 7.0 & $2.017 \mathrm{E}-6$ & $495.78 \pm 1.58$ & 494.21 & 0.00204 & $1.02 \pm 0.30$ \\
\hline Dis-assembled state @ pH 1.5 & $37.764 \mathrm{E}-6$ & $26.49 \pm 5.97$ & 20.59 & -0.01860 & $-9.30 \pm 5.42$ \\
\hline Re-assembled state @ pH 7.0 & $2.039 \mathrm{E}-6$ & $490.44 \pm 3.76$ & 494.21 & -0.00038 & $-0.19 \pm 0.08$ \\
\hline
\end{tabular}

Table S4: Potential protonation/deprotonation sites in bullfrog $\mathrm{M}$ ferritin based on pH-dependent electrostatic (PROPKA) analysis as described in the Experimental Section.

\begin{tabular}{|c|c|}
\hline Location & Amino Acid Residues \\
\hline Dimer (2-fold) Interface & His45, His56 \\
\hline 3-fold pore & His9, His114, His124 \\
\hline 4-fold pore & His45, His169 \\
\hline
\end{tabular}


The non-linear curve fitting for the kinetics of ferritin self-assembly were performed using the following set of equations (as shown below) and the fitting parameters are listed in Table S5; where $\mathrm{y}_{0}=$ offset value; $\mathrm{A}_{1}=$ amplitude of rapid phase and $\mathrm{A}_{2}=$ amplitude of slow phase; $[\mathrm{p}]_{0}=$ protein (subunit) concentration; $\mathrm{t}_{1 / 2}=$ half-life, $\left(\mathrm{t}_{1 / 2}\right)_{1}=$ half-life of rapid phase and $\left(\mathrm{t}_{1 / 2}\right)_{2}=$ halflife of slow phase; $\tau_{1}=$ average lifetime of rapid phase and $\tau_{2}=$ average lifetime of slow phase; $\mathrm{v}_{\max }=$ maximum rate/velocity, $\mathrm{k}=$ Michaelis-Menten constant and $\mathrm{n}=$ Hill coefficient.

\section{(1). Single Exponential Equation:}

$y=y_{0}+A_{1} \cdot e^{x / \tau_{1}}$

\section{(2). Hyperbolic Equation:}

Norm. Intensity $=1-\frac{1}{[\mathrm{p}]_{0} \frac{t}{\mathrm{t}_{1 / 2}}+1}$

\section{(3). Exponential (first order kinetic) Equation:}

Norm. Intensity $=1-\exp \left(-\frac{0.693 \mathrm{t}}{\mathrm{t}_{1 / 2}}\right)$

(4). Hill Equation:

$y=v_{\max } \cdot\left(\frac{x^{n}}{k^{n}+x^{n}}\right)$

\section{(5). Double Exponential Equation:}

$y=y_{0}+A_{1} \cdot e^{x / \tau_{1}}+A_{2} \cdot e^{x / \tau_{2}}$

\section{(6). Double Hyperbolic Equation:}

Norm.Intensity $=1-\frac{\mathrm{A}_{1}}{[\mathrm{p}]_{0} \frac{t}{\left(\mathrm{t}_{1 / 2}\right)_{1}}+1}-\frac{\mathrm{A}_{2}}{[\mathrm{p}]_{0} \frac{t}{\left(\mathrm{t}_{1 / 2}\right)_{2}}+1}$ 
Table S5: Fitting Parameters for non-linear curve fitting of the kinetics of self-assembly reaction of ferritin under different reaction conditions.

\section{Adjacent $\mathbf{R}^{2}$}

\begin{tabular}{|c|c|c|c|c|c|c|c|}
\hline $\begin{array}{c}\text { Physical } \\
\text { Parameters }\end{array}$ & Variation & $\begin{array}{c}\text { Single } \\
\text { Exponential } \\
\text { Fitting }\end{array}$ & $\begin{array}{c}\text { Hyperbolic } \\
\text { Fitting }\end{array}$ & $\begin{array}{c}\text { Exponential } \\
\text { (1 }{ }^{\text {st }} \text { Order } \\
\text { Kinetic) } \\
\text { Fitting }\end{array}$ & $\begin{array}{c}\text { Hill } \\
\text { Fitting }\end{array}$ & $\begin{array}{c}\text { Double } \\
\text { Exponential } \\
\text { Fitting }\end{array}$ & $\begin{array}{c}\text { Double } \\
\text { Hyperbolic } \\
\text { Fitting }\end{array}$ \\
\hline \multirow{3}{*}{$\begin{array}{l}\text { Concentration } \\
(\mathrm{mg} / \mathrm{mL})\end{array}$} & 0.05 & 0.69 & 0.73 & 0.17 & 0.89 & 0.97 & 0.92 \\
\hline & 0.15 & 0.69 & 0.65 & 0.24 & 0.92 & 0.94 & 0.91 \\
\hline & 0.25 & 0.86 & 0.54 & 0.41 & 0.79 & 0.87 & 0.93 \\
\hline \multirow{3}{*}{ Final $\mathrm{pH}$} & 5.50 & 0.88 & 0.89 & 0.71 & 0.94 & 0.95 & 0.94 \\
\hline & 6.50 & 0.82 & 0.87 & 0.54 & 0.96 & 0.99 & 0.96 \\
\hline & 7.50 & 0.87 & 0.94 & 0.58 & 0.98 & 0.99 & 0.98 \\
\hline \multirow{3}{*}{$\begin{array}{c}\text { Ionic } \\
\text { Strength } \\
\text { (M) }\end{array}$} & 0.55 & 0.77 & 0.79 & 0.38 & 0.93 & 0.95 & 0.93 \\
\hline & 0.60 & 0.77 & 0.86 & 0.60 & 0.95 & 0.83 & 0.95 \\
\hline & 0.70 & 0.91 & 0.87 & 0.83 & 0.57 & 0.92 & 0.88 \\
\hline \multicolumn{8}{|c|}{ Reduced $\chi^{2}$} \\
\hline $\begin{array}{c}\text { Physical } \\
\text { Parameters }\end{array}$ & Variation & $\begin{array}{c}\text { Single } \\
\text { Exponential } \\
\text { Fitting }\end{array}$ & $\begin{array}{c}\text { Hyperbolic } \\
\text { Fitting }\end{array}$ & $\begin{array}{c}\text { Exponential } \\
\left(1^{\text {st }} \text { Order }\right. \\
\text { Kinetic) } \\
\text { Fitting }\end{array}$ & $\begin{array}{c}\text { Hill } \\
\text { Fitting }\end{array}$ & $\begin{array}{c}\text { Double } \\
\text { Exponential } \\
\text { Fitting }\end{array}$ & $\begin{array}{c}\text { Double } \\
\text { Hyperbolic } \\
\text { Fitting }\end{array}$ \\
\hline \multirow{3}{*}{$\begin{array}{c}\text { Concentration } \\
(\mathrm{mg} / \mathrm{mL})\end{array}$} & 0.05 & 0.00263 & 0.00225 & 0.00690 & 0.00093 & 0.00022 & 0.00068 \\
\hline & 0.15 & 0.00126 & 0.00141 & 0.00307 & 0.00033 & 0.00026 & 0.00036 \\
\hline & 0.25 & 0.00029 & 0.00096 & 0.00125 & 0.00043 & 0.00026 & 0.00014 \\
\hline \multirow{3}{*}{ Final $\mathrm{pH}$} & 5.50 & 0.00066 & 0.00059 & 0.00163 & 0.00028 & 0.00036 & 0.00066 \\
\hline & 6.50 & 0.00131 & 0.00092 & 0.00335 & 0.00009 & 0.00025 & 0.00131 \\
\hline & 7.50 & 0.00171 & 0.00079 & 0.00569 & 0.00011 & 0.00031 & 0.00171 \\
\hline \multirow{3}{*}{$\begin{array}{c}\text { Ionic } \\
\text { Strength } \\
\text { (M) }\end{array}$} & 0.55 & 0.00130 & 0.00116 & 0.00349 & 0.00038 & 0.00029 & 0.00038 \\
\hline & 0.60 & 0.00119 & 0.00070 & 0.00204 & 0.00027 & 0.00087 & 0.00024 \\
\hline & 0.70 & 0.00027 & 0.00041 & 0.00054 & 0.00132 & 0.16691 & 0.00040 \\
\hline
\end{tabular}



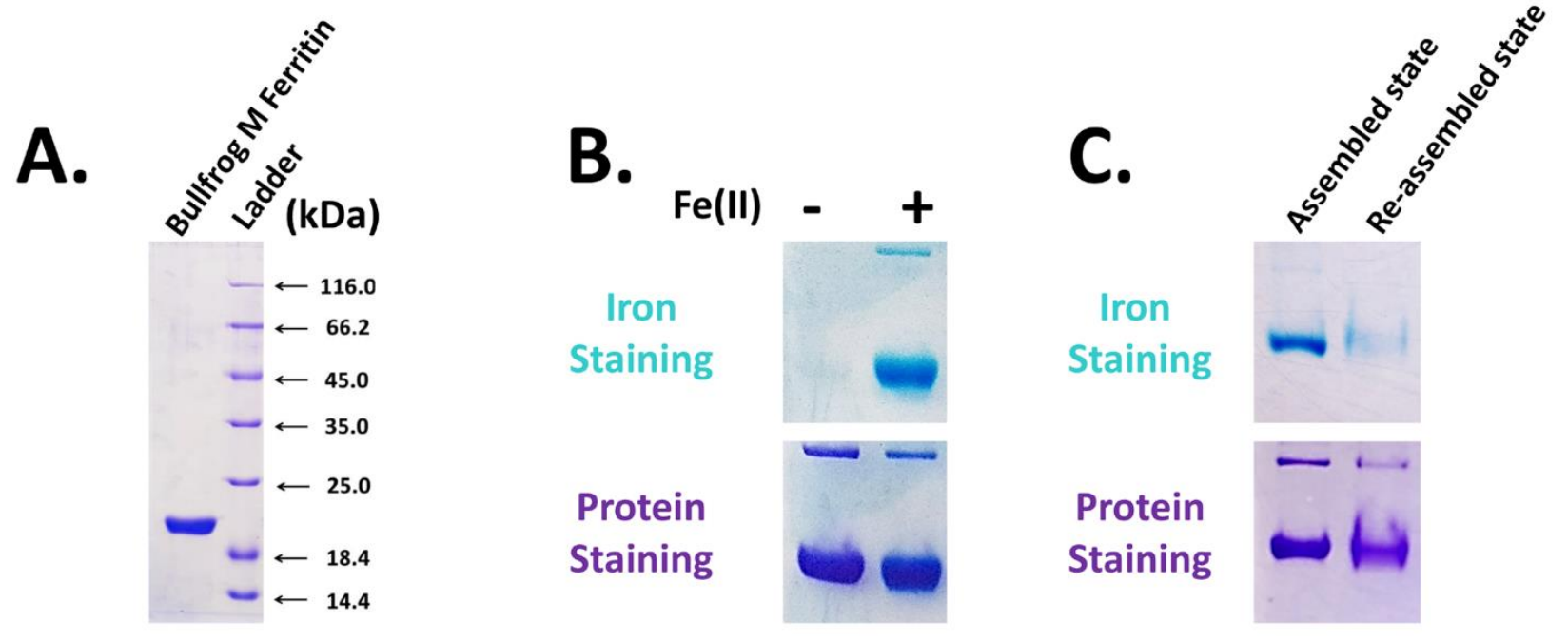

Figure S1: Purity, cage integrity and iron loading ability of bullfrog $M$ ferritin nanocages by SDS-PAGE and native PAGE. (A) The purified bullfrog M ferritin ( 20.6 kDa, 171 amino acids) on a $12.5 \%(\mathrm{w} / \mathrm{v})$ of SDS polyacrylamide gel. The molecular weights (in $\mathrm{kDa})$ of the ladder are indicated at the right lane. Bullfrog M ferritin protein samples in: (B) its apo-form ('-' sign) and mineralized form ('+' sign) and (C) in its assembled state and re-assembled state, were run in a $5 \%(\mathrm{w} / \mathrm{v})$ non-denaturing gel, at $100 \mathrm{~V}$ for $1 \mathrm{~h}\left(4^{\circ} \mathrm{C}\right)$. The gels were further treated with acidified $\mathrm{K}_{4}\left[\mathrm{Fe}(\mathrm{CN})_{6}\right]$ (Iron staining by Prussian blue formation; top) and Coomassie brilliant blue (protein staining; bottom). The strong intense bands at the bottom of each gel indicate the 24-mer ferritin nanocage, while the weak faint bands at the top correspond to the cage multimers/aggregates. Note: Low intensity of bands in iron staining profile of re-assembled ferritin in (C) is attributed to the phosphate buffer (used for re-assembling the ferritin subunits) that chelates iron during mineralization. 

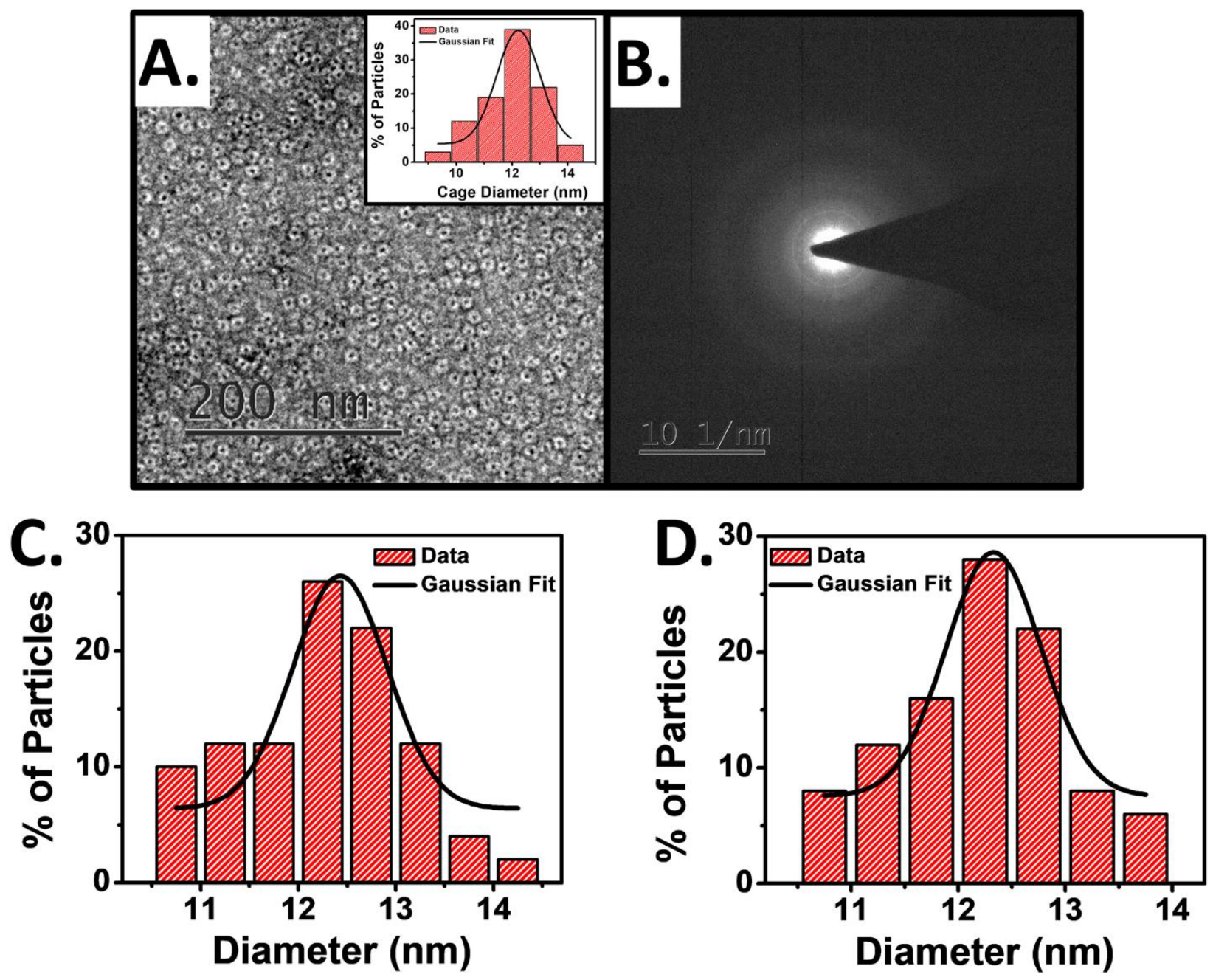

Figure S2: TEM based size analysis, cage integrity and iron loading of ferritin protein nanocages by TEM. (A) TEM image of mineralized bullfrog $\mathrm{M}$ ferritin nanocages (480 Fe/Cage; Inset: Histogram representing the size distribution profile for the outer dimension of ferritin protein nanocages). The mean diameter and size distribution of the sample were obtained from a statistical analysis over $~ 50$ ferritin nanoparticles) (B) Selected area electron diffraction (SAED) pattern of the iron mineral core formed inside ferritin protein nanocages. The SAED pattern indicated somewhat "less crystalline"/amorphous nature of the ferritin's central iron mineral whose size was determined as $5.0( \pm 0.8) \mathrm{nm}$ (from TEM images of unstained ferritin samples). Histogram representing the size distribution of ferritin protein nanocages in their: $(\mathbf{C})$ assembled state at $\mathrm{pH} 7.0$ prior to dis-assembly and (D) re-assembled state at $\mathrm{pH} 7.0$ following self-assembly. The size was determined from statistical analysis of over 50 particles using ImageJ software for the TEM micrographs as shown in Fig.2.A-C. 


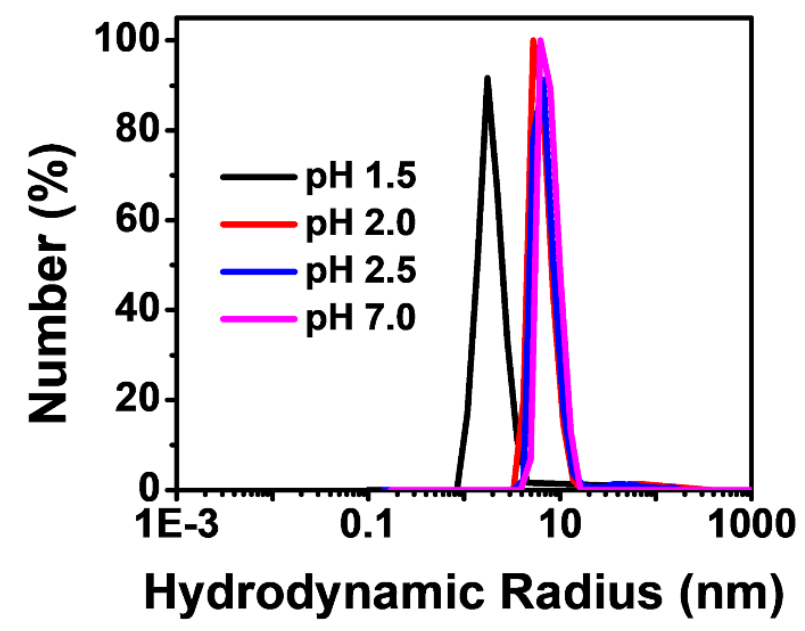

Figure S3: Effect of $\mathbf{p H}$ on the size distribution of ferritin protein nanocages. Number based size distribution profile (determined by DLS) of ferritin protein nanocages incubated at different $\mathrm{pH}$.
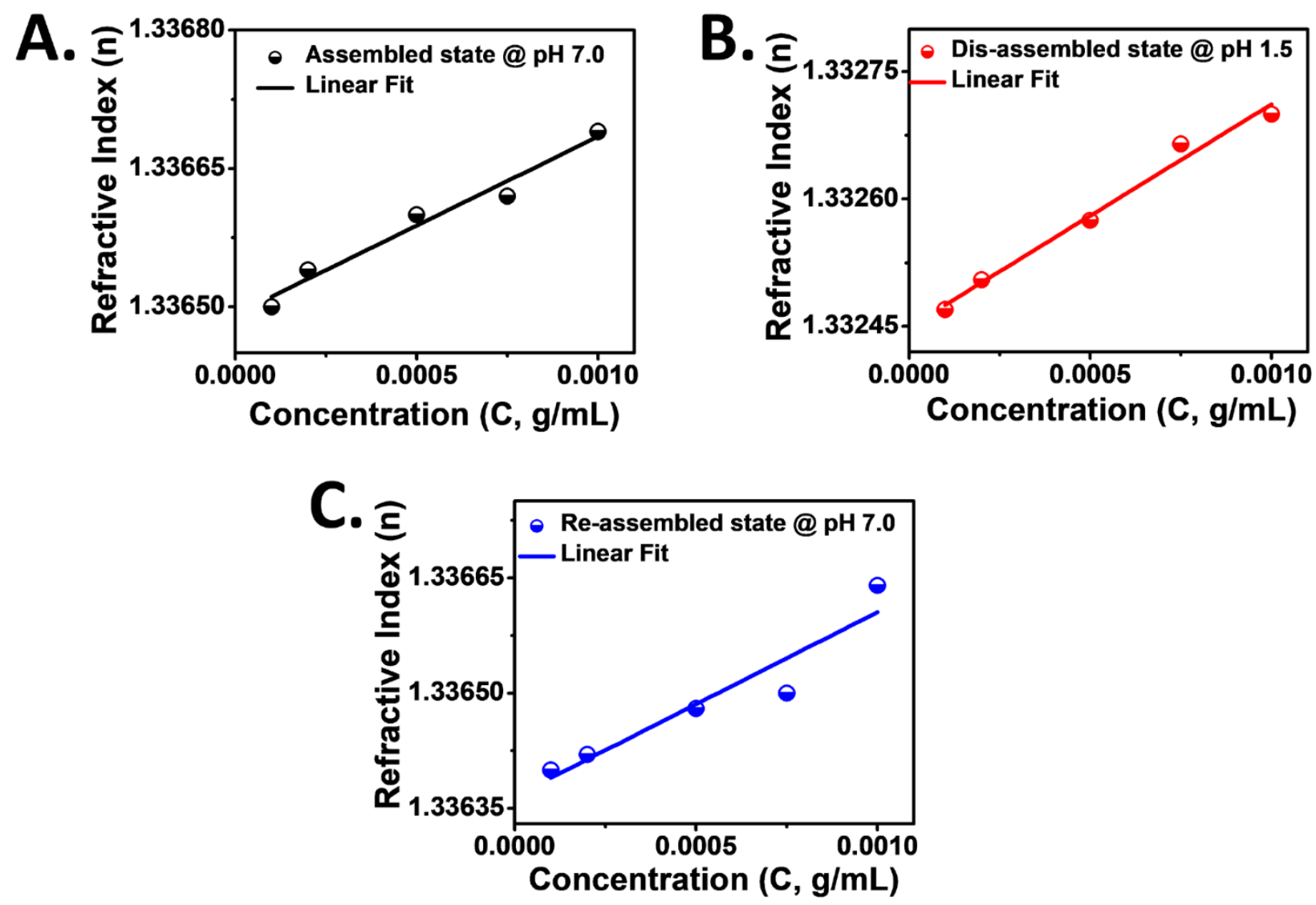

Figure S4: Determination of refractive index increment $(\mathbf{d n} / \mathbf{d C})$. The refractive index (n) plotted as a function of ferritin protein concentration $(0.1-1.0 \mathrm{mg} / \mathrm{mL})$ in their $(\mathbf{A})$ assembled, $(\mathbf{B})$ 
dis-assembled and $(\mathbf{C})$ re-assembled state. The $\mathrm{dn} / \mathrm{dC}$ values were determined from the slope of the linear fitting of the data points and are quoted in Table S2.
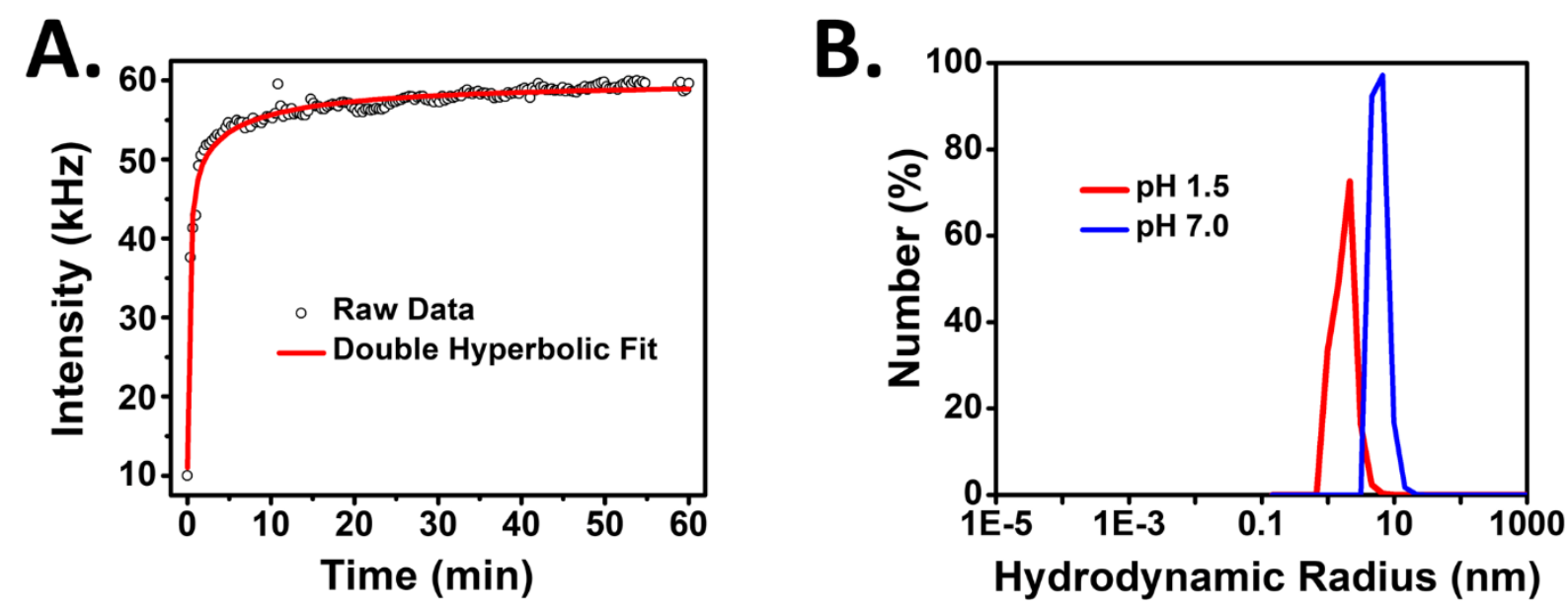

Figure S5: Kinetics of ferritin self-assembly by laser light scattering. (A) Kinetics of ferritin self-assembly, which was disassembled at $\mathrm{pH} 1.5$ and then reassembled at $\mathrm{pH}$ 7. (B) The corresponding DLS size distribution profile for the disassembled and reassembled samples recorded at the beginning and at the end of self-assembly reaction kinetics, respectively. Protein concentration was maintained at $0.10 \mathrm{mg} / \mathrm{mL}$ while ionic strength was fixed at $0.450 \mathrm{M}$. 

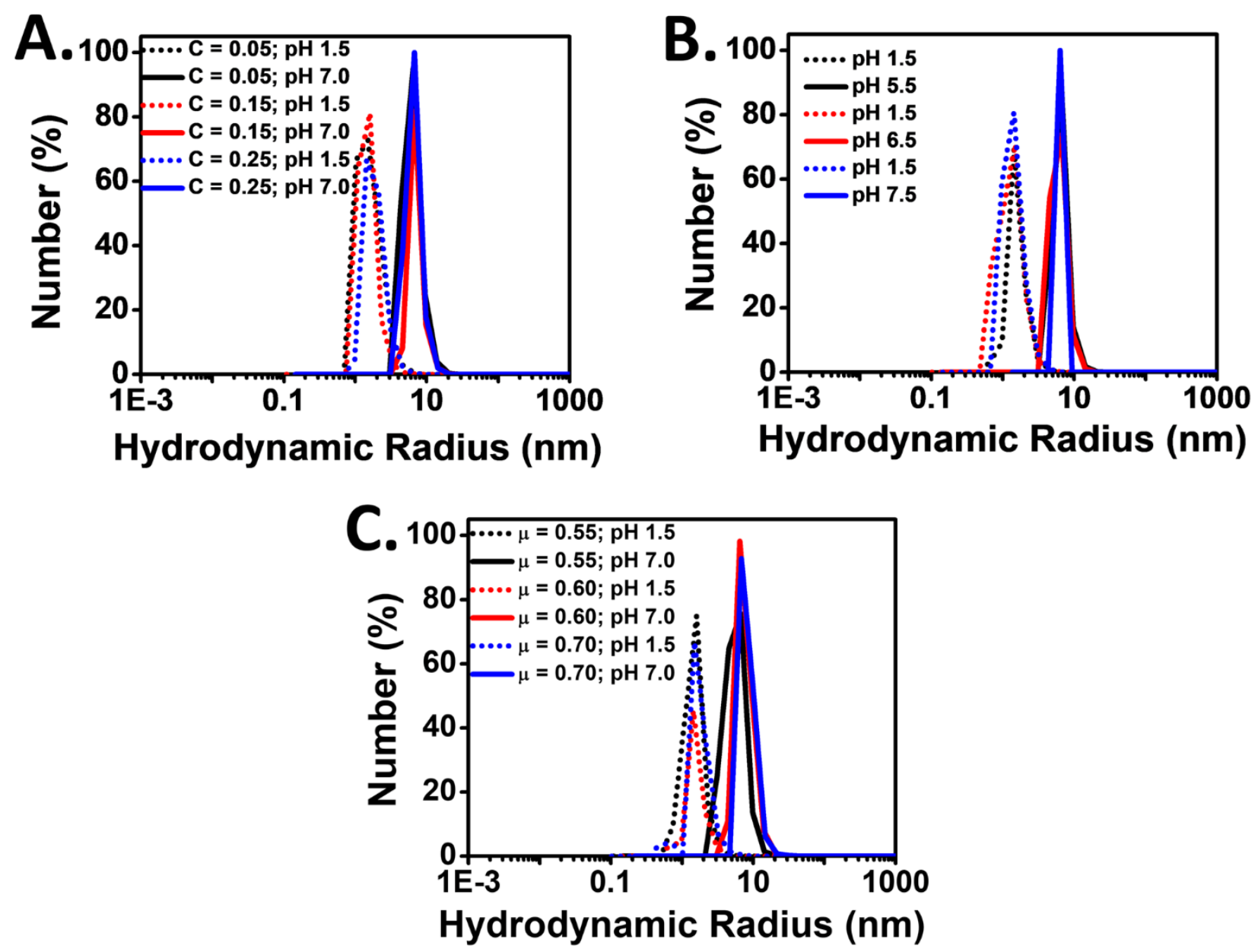

Figure S6: Effect of various factors on the size distribution of dis-assembled/re-assembled ferritin protein nanocages. The DLS based number distribution size profile for the disassembled (dotted lines; recorded prior to the initiation of self-assembly reaction kinetics) and reassembled (solid lines; recorded at the end of self-assembly reaction kinetics) samples whose kinetics of self-assembly was monitored under varying reaction conditions (also mentioned in Fig.4). (A) The protein concentration was varied from 0.05 to $0.25 \mathrm{mg} / \mathrm{mL}$ and was disassembled at $\mathrm{pH} 1.5$ and re-assembled at $\mathrm{pH}$ 7.0. (B) The final $\mathrm{pH}$ of the medium was varied from 5.5 to 7.5 for re-assembling the protein which was dis-assembled at $\mathrm{pH} 1.5$ (concentration was maintained at $0.100 \mathrm{mg} / \mathrm{mL}$ ). (C) The ionic strength of the medium ( $\mu$ ) was varied from 0.55 $\mathrm{M}$ to $0.70 \mathrm{M}$ keeping protein concentration and final $\mathrm{pH}$ of the medium fixed at $0.100 \mathrm{mg} / \mathrm{mL}$ and 7.0, respectively. The values determined from these DLS profiles are also quoted in Table S1. 

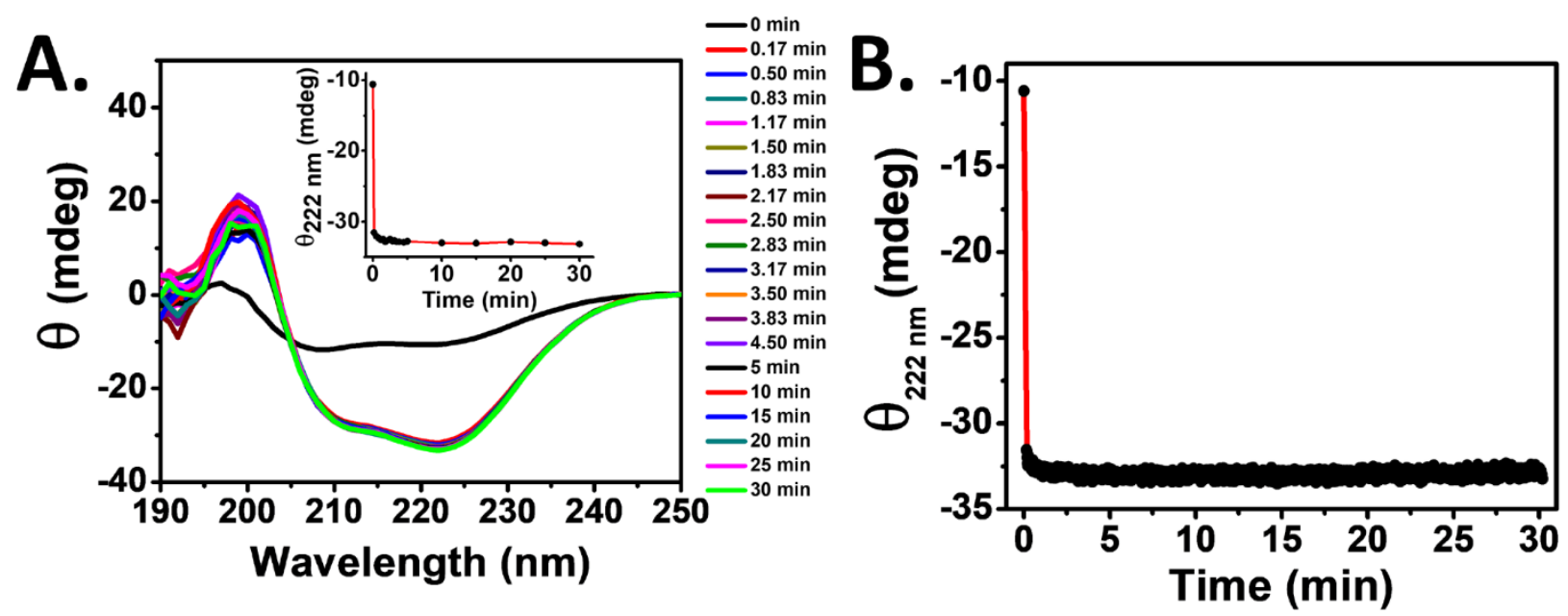

Figure S7: Analysis of ferritin self-assembly reaction by CD spectroscopy. (A) Far-UV CD spectra of ferritin protein recorded at different time intervals upon increasing the $\mathrm{pH}$ of the medium (from 1.5 to 7.0 ) to carry out the assembly reaction (Inset: Time course of CD signal at $222 \mathrm{~nm}\left(\theta_{222} \mathrm{~nm}\right)$; data points were obtained from the spectra). (B) Kinetics of changes in CD signal at $222 \mathrm{~nm}\left(\theta_{222} \mathrm{~nm}\right)$ during the self-assembly reaction of ferritin keeping the CD monochromator fixed at $222 \mathrm{~nm}$. Protein concentration was maintained at $0.25 \mathrm{mg} / \mathrm{mL}$.

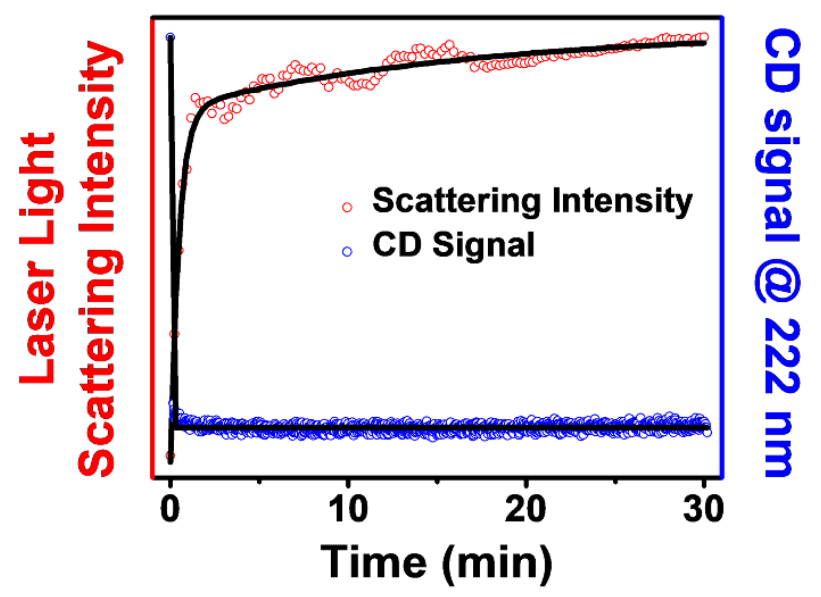

Figure S8: Simultaneous monitoring of ferritin self-assembly reaction by investigating the time course of changes both in the laser light scattering intensity as well as in the CD signal at $222 \mathrm{~nm}\left(\theta_{222} \mathrm{~nm}\right)$. CD monochromator was fixed at $222 \mathrm{~nm}$ and protein concentration was maintained at $0.05 \mathrm{mg} / \mathrm{mL}$. 


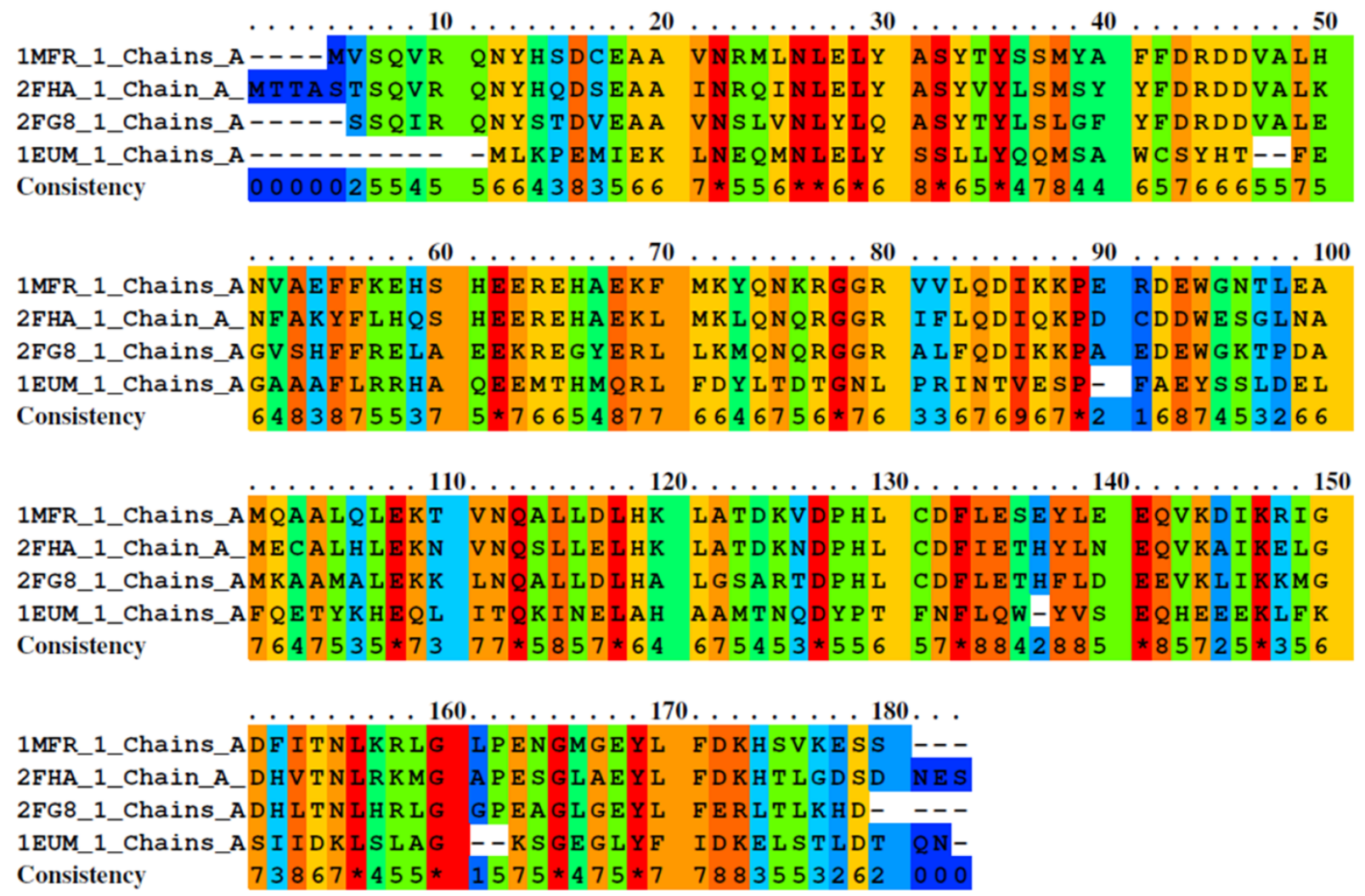

Figure S9: Sequence alignment of bullfrog M ferritin (1MFR), human H chain ferritin (2FHA), human L chain ferritin (2FG8) and Escherichia coli ferritin A (1EUM). The current colour scheme of the alignment is for amino acid conservation. The conservation scoring is performed by PRALINE. The scoring scheme works from 0 for the least conserved alignment position, up to 10 for the most conserved alignment position. Amino acid position (numbering) is based on human $\mathrm{H}$ chain ferritin. 